\title{
RUTHENIAN PROTESTANTS OF THE GRAND DUCHY OF LITHUANIA AND THEIR RELATIONSHIP WITH ORTHODOXY, 1569-1767
}

\author{
Andrej Kotljarchuk
}

\begin{abstract}
In the nineteenth century when the process of the formation of modern ethnic identity in Eastern Europe started, Belarus lost its educated strata, the Ruthenian elite, the potential leadership of this movement. That happened for a number of reasons. Among them, there was the success of the Counter-Reformation over Protestantism and Orthodoxy in Belarus and Lithuania. After 1667 Catholicism became the sign of political loyalty to the Polish-Lithuanian Commonwealth. As a result, step by step the Ruthenian nobility and the upper class of townspeople of Orthodox and Protestant faiths adopted Polish religious and cultural identity under the formula 'gente ruthenus, natione polonus.' Very little has been written about the ethnic Ruthenian nobility of the Grand Duchy of Lithuania, especially its Protestant group. The aim of this article is to present an overview of the relationship between the early modern Protestant and Orthodox parts of the Ruthenian elite and their correlated identity.
\end{abstract}

Introduction In the nineteenth century, when the process of the formation of modern ethnic identities in Eastern Europe started, Belarus lost its educated strata, the Ruthenian elite, which formed a potential leadership of this movement. That happened for a number of reasons. Among them, there was the success of the Counter-Reformation over Protestantism and Orthodoxy in Belarus and Lithuania. After 1667 Catholicism became the sign of political loyalty to the Polish-Lithuanian Commonwealth. As a result step by step the Ruthenian nobility and the upper lass of townspeople of Orthodox and Protestant faiths adopted Polish religious and cultural identity under the formula of 'gente ruthenus, natione polonus.' Very little has been written about the ethnic Ruthenian nobility of the Grand Duchy of Lithuania, especially its Protestant group. The aim of this article is to present an overview of the relationship between the early modern Protestant and Orthodox parts of the Ruthenian elite and their correlated identity. 
The Ruthenian Nation of the GDL Historically, all Ruthenians (Eastern Slavs) from the eleventh century belonged to the Greek Orthodox Church and all Lithuanians (Balts) from the end of fourteenth century were Roman Catholics. Thus, until the mid-sixteenth century, the political elite of the GDL fell into two groups: one Orthodox and the other, Catholic. ${ }^{1}$ The GDL was an independent state until 1569, when a federation with Poland was created. People of different ethnic groups inhabited the country; the majority of the population comprised Eastern Slavs and Balts. In addition, there were Jews, Poles, Lithuanian Tartars and Germans. The political elite consisted mostly of the Lithuanian (both Lithuanian and Žemaitian) and Ruthenian nobility in an ethnical sense, although both groups were known as 'Lithuanians'. This term had a political, rather than an ethnical meaning. ${ }^{2}$ According to the Third Statute of 1588, only indigenous Lithuanian, Ruthenian and Žemaitian nobles by origin could take the GDL state positions. ${ }^{3}$ Ruthenian lands formed the largest part of the GDL. The official language was Ruthenian. ${ }^{4}$ Until the beginning of the seventeenth century, Ruthenian was the lingua franca of the multiethnic nobility. Contemporary historians noted that in the native vernacular of the Lithuanian nobility: 'Several Italian and Latin words intermix with its present language. As likewise most of the noble families, who the vulgar sort are altogether Slavonic'. 5

${ }^{1}$ V. Varonin, 'Political system of Polatsk voivodship in the first half of the 16th century', Belarusian Historical Review, vol. 5, no. 1(8) (1998), pp. 27-66.

${ }^{2}$ During the nineteenth and early twentieth centuries two modern national projects (Belarusian and Lithuanian) were created on the former soil of the Grand Duchy of Lithuania. A very small number of the representatives of the historical Grand Duchy gentry took part in both of the movements. See: T. Snyder, The Reconstruction of Nations. Poland, Ukraine, Lithuania, Belarus, 1569-1999 (New Haven-London, 2003), pp. 13-102.

${ }^{3}$ The 1588 Statute of the Grand Duchy of Lithuania, Ruthenia and Žemaitija (chapter 3, article 12), see: Statut Vialikaha Kniastva Litouskaha 1588 (Minsk, 1989), p.118.

${ }^{4}$ For some historians the Ruthenian or Belarusian language (the latter term came into use from the seventeenth century) was the dead 'Chancery Slavonic language'. According to philologists the Ruthenian language was alive and similar to popular Belarusian dialects and modern literary language. It was the lingua franca for the multiethnic Lithuanian nobility, native vernacular for Ruthenian gentry, a language of the old Belarusian literature and the GDL's official language according to the 1588 Statute (chapter 4, article 1). See: S. Lazutka, 'Język Statutów Litewskich i Metryki Litewskiej’, Lithuania, no. 1-2 (22-23) (1997), pp. 26-33.

${ }^{5}$ B. Connor, The history of Poland (London, 1698), p. 306. 
Thus, the GDL political nation was poly-ethnic. For example, one branch of the old Ruthenian princely family of Puzyna settled in the district of Upyte. During the seventeenth century this branch of the family converted to Calvinism and assimilated with its ethnically non-Slavic neighbours. ${ }^{6}$ Another branch of the Puzyna line, which settled among the Ruthenians, resisted Polonization and preserved its East Slavic identity. In the mid-seventeenth century, the head of this branch, Afanasiusz Puzyna, became the Orthodox bishop of Lutsk. Later, members of the Puzyna family would take part in three different national movements (Lithuanian, Belarusian and Ukrainian). Jonas Puzinas became a prominent Lithuanian archaeologist. Another example is the ethnic Lithuanian family of Giedroyć. Two members of this family became prominent activists of both Lithuanian and Ruthenian culture. Melchior Giedroyć (Merkelis Giedraitis) was Roman Catholic bishop of Žemaitija (1576-1609). He re-established Catholicism in his diocese after the Reformation and is considered a great ethnic Lithuanian patriot. However, Melecjusz Giedroyć (Mialecij Hiedroyc) was the superior of the Orthodox monastery in Polotsk. After the union with Poland, a considerable number of ethnic Polish nobles entered into the service of Lithuanian magnates, and sometimes made up an important part of the local nobility. ${ }^{7} \mathrm{~A}$ similarly structured political elite could be found elsewhere in early modern Europe. For example, the political elite of Transylvania included three ethnic groups: Hungarians, Szkelers and Germans. The nobility of Bohemia consisted of Czechs and Germans.

Ruthenian nobles of the GDL were ruled by the ethnic Lithuanian dynasty of Jagellonians, which resulted in the transition of the Ruthenian elite to their jurisdiction. The nobility of Pinsk (from the former Kievan Realm) held that they 'together with their towns' had accepted the rule of Lithuania voluntarily, and that their Principality was divided into districts of Lithuania since the last Rurikid, Duke Fedor Jaroslavovich, died without heirs. ${ }^{8}$ The early modern identity of the Ruthenians was formed during their struggles

\footnotetext{
${ }^{6} \mathrm{M}$. Liedke, Od prawostawia do katolicyzmu. Ruscy możni i szlachta Wielkiego Księstwa Litewskiego wobec wyznań reformacyjnych (Białystok, 2004), p. 232.

${ }^{7}$ M. Topolska, 'Środowisko twórcze w Wielkim Księstwie Litewskim w XVI wieku', Studia nad gospodarka, społeczeństwem i rodzinq w Europie późnofeudalnej, ed. J. Topolski, C. Kuklo (Lublin, 1987), pp. 195-216.

${ }^{8}$ A. Korshunov, Afanasiusz Filipowicz. Zhizn' $i$ tvorchestvo (Minsk, 1965), p. 99.
} 
against Muscovy. Russia's lengthy wars against Lithuania (1492-94, 1500-1503, 1507-08, 1512-22, 1534-37, 1632-34) contributed to a negative image of Muscovite Russians among Lithuanian Ruthenians. During the wars with Moscow, the Orthodox Ruthenian population and the clergy were loyal to Vilnius. ${ }^{9}$ Until the mid-seventeenth century, the Lithuanian and Muscovite Orthodox religious rites were different. The long separation of the Churches since 1415 had caused this difference. Whereas the Moscow Patriarchate elaborated a specific sequence of religious ceremonies and rites (the two-finger sign of the cross, different duration of divine service and liturgical order), the Ruthenian Orthodox Church, which remained under the jurisdiction of the ecumenical Patriarch of Constantinople, preserved the original Greek tradition. In Ruthenian chronicles, the Muscovites were often treated as 'foes' and 'enemies'. 10

After the 1569 Union with Poland the GDL had kept its own separate legal system, which was based on the 1588 Statute, drafted in Ruthenian and later in Polish. ${ }^{11}$ The Commonwealth had two different official languages: Latin was used in Poland and Ruthenian (written with Cyrillic script) in Lithuania. Because of this, the editor of the 1588 Statute, the Chancellor Lew Sapieha, wrote in his address to all of the estates: 'Every nation should be ashamed not to know its own laws, especially for us who use our native language in which we record the laws and at any time we can take advantage of it to defend ourselves from injustice'. ${ }^{12}$

No wonder that the European image of Lithuania was similar to that of Scotland: 'The Great Duchy of Lithuania called by the inhabitants Litwa, the subject to the King of Poland as Scotland to the King of England, yet is a different Nation from the Kingdom'. ${ }^{13}$

The Protestant Reformation Religious dissidents such as the Bohemian Brethren (Jerome of Prague) visited the GDL as early as 1420. Between 1523 and 1546, twenty young Grand Duchy magnates

${ }^{9}$ M. Krom, Mezhdu Rus'u i Litvoi. Zapadnorusskie zemli v sisteme russko-litovskikh otnoshenii kontsa XV-pervoi treti XVI veka (Moscow, 1995).

${ }^{10}$ I. Marzaljuk, 'Nasha 'Kieuskaya' i 'Litouskaya' spadchyna', Spadchyna, 2002, no. 5-6.

${ }^{11}$ L. Okinshevich, The Law of the Grand Duchy of Lithuania. Background and Bibliography (New York, 1953).

${ }^{12}$ Statut Vialikaha Kniastva Litouskaha, p. 17.

${ }^{13}$ Connor, History, p. 302. 
attended Martin Luther's lectures at the University of Wittenberg. ${ }^{14}$ The Protestant Reformation in the GDL started under the guise of Lutheranism, and was inspired by neighbouring Ducal Prussia and Livonia. The first Evangelical church was founded in Žeimelis (Žemaitija) in 1540. In 1555, a Lutheran church was established in Vilnius. ${ }^{15}$ In 1553 Duke Mikalojus Radvila [Radziwiłł] the Black converted from Catholicism to Lutheranism in Brest and founded there the first Lutheran parish on Ruthenian soil. Conversion to Protestantism became very popular among the Catholic and Orthodox gentry. At the end of the sixteenth century, the Reformation spread in Belarus. ${ }^{16}$

The Reformation contributed a lot to the development of ethnic Ruthenian and Lithuanian cultures. In 1547 in Königsberg Martynas Mažvydas, a refugee from Lithuania, issued a short Lutheran Catechism, the first book ever published in Lithuanian. ${ }^{17}$ In 1562, Simon Budny, supported by the Radvila family, in Niasvizh published a Lutheran Catechism in Ruthenian - the first book to be published in the territory of modern Belarus. In 1572, the Protestant nobleman Wasyl Ciapiński published the New Testament in the Ruthenian language, in his own typography and with a patriotic introduction dedicated to his native culture. ${ }^{18}$ A great number of Calvinist and Arian manuscript psalters and hymnals in Ruthenian dating back to the second half of the sixteenth and the seventeenth centuries have been preserved. ${ }^{19}$ At the same period, in 1590 at Königsberg, the Lutheran scholar Jonas Bretkūnas translated the Bible into Lithuanian. ${ }^{20}$ In 1653, the first Calvinist Catechism and psalms in

${ }^{14}$ J. Malek, 'Polscy i litewscy studenci na uniwersytecie królewieckim', Polska $i$ jej wschodni sqsiedzi od średniowiecza po współczesność (Torun, 1996), p. 179.

${ }^{15} \mathrm{H}$. Merchyng, 'Zbory i senatorowie protestancy w dawnej Polsce: przyczynki do dziejów terytorialnego i chronologicznego rozwoju i upadku reformacji w Rzeczypospolitej', Krasiński Walerjan, Zarys dziejów powstania i upadku reformacji $w$ Polsce, Vol. 2, (Warsaw, 1986).

${ }^{16}$ M. Pačkajeu, 'Evangelical Altar Furnishings in Belarus (16th -19 th centuries)', Belarusian Chronicle, no. 18, 2001, pp. 10-14.

${ }^{17}$ The first Lithuanian book and its cultural context: Martinus Mosvidius' Catechismus, 1547, ed. S. Žukas (Vilnius, 1996).

${ }^{18}$ Kniha Belarusi. Zvodny katalah. 1517-1917 (Minsk, 1986), no 12.

${ }^{19}$ V. Lastouski, Historya belaruskaj (kryuskaj knihi). Sproba pajasnitselnaj knihapisi ad kantsa X da pachatku XIX stahodzdzia (Kaunas 1926), pp. 383-395.

${ }^{20}$ J. Range, Bausteine zur Bretke-Forschung (Paderborn, 1992). 
Lithuanian were published in Kedainiai. ${ }^{21}$ This edition was prepared by the two superintendents, Jan Borzymowski and Samuel Minwid, and was sponsored by Jonušas Radvila. In this edition Radvila was styled 'Primate of Lithuania' in an analogy to the title of the leader of the Roman Catholic Church - the bishop of Vilnius. ${ }^{22}$

From the very beginning, the GDL Reformation had an elite nature. It developed mainly as a Church of nobles. The Union of three Protestant denominations of nobility was proclaimed as a Jednota Litewska (Lithuanian Unity) in Vilnius in 1578. This institution united the Major Church (Calvinists) and the Minor Church (the Lithuanian Brethren, also known as the Arians or Socinians or AntiTrinitarians or Unitarians). The Lithuanian Unity also included and supported about 20 Lutheran parishes led by its own superintendent. The Lithuanian Unity was organized into six districts: three of them within the present-day Lithuania, and three of them in the Belarusian area, namely: the District of Belarus (Kojdanava/Dziarzhynsk); the District of Novgorodok (with the centre at the Slutsk cathedral church) and the District of Podlasie (Zabludów).

Around the year 1600, 260 Evangelical churches were active in the GDL. ${ }^{23}$ There were, at that time, more Protestant congregations than Catholic parishes in the Vilnius bishoprics. ${ }^{24}$ However, 92 per cent of the Evangelical churches were in western and northern parts of the Duchy. To the east of Minsk, in the districts that made up about 40 per cent of the territory, only ten churches were founded. Owing to Catholic opposition, the Protestants did not succeed in establishing their own university. Nevertheless, in 1625, the synod of Jednota Litewska decided to set up two grammar schools. Therefore Kèdainiai became an educational centre for students from the territories that were ethnically Lithuanian (Vilnius, the area beyond the River

${ }^{21}$ I. Lukšaitè, Apie lietuvišku reformatu knygu plitima Lietuvoje XVII a. (Vilnius, 1970).

${ }^{22}$ Knyga nobažnystès krikščioniškos 1653. (Vilnius, 2004), p. 10.

${ }^{23}$ The Polish Brethren: documentation of the history and thought of Unitarianism in the Polish-Lithuanian Commonwealth and in the diaspora, 1601-1685. Ed., tr., G. Huntston Williams. [= The Proceedings of the Unitarian Historical Society, XVIII] (Cambridge, 1978-79), pp. 373-374.

${ }^{24}$ M. Kosman, 'Programme of the Reformation in the Grand Duchy of Lithuania and how it was carried through (c 1550 - c 1650)', Acta Poloniae Historica, 35 (1977), p. 27 (25-50). 
Neris and Žemaitija). The Slutsk grammar school became a centre for Ruthenian students (Novgorodok, Podlasie and Belarus). ${ }^{25}$

Protestantism became extremely popular among the Ruthenian gentry. ${ }^{26}$ The Muscovite political emigrant, Andrei Kurbskii wrote in the 1570s about the essential dissemination of Lutheranism among the local Ruthenian nobility, not to mention the Ruthenian nobility of Polish-controlled Ukraine. ${ }^{27}$ In my opinion, the Reformation attracted the Ruthenians through its closeness with the principles of native Orthodoxy: the absence of celibacy among the secular clergy, divine service in the vernacular, the congregation of believers under two sacraments (bread and wine), the essential role of laity in congregation, control over the church manors. From the end of the sixteenth century, the Reformation spread among the Orthodox nobility in eastern districts. New Evangelical churches appeared in Vitebsk, Polotsk, Mogilev, Lukoml, Shklou, Sakolnia, Orsha, Novy Bykhov, Kopys, Kniazhychy and Halouchyn. The district of Braslau, close to Courland and Livonia, became the centre of the Reformation in the northern part of Belarus, where the Protestant nobility, led by old local Ruthenian families of Mirskii and Puciata, preserved their power during the whole period of the Catholic reaction.

\section{Attempts of Ruthenian Protestants to Construct their Own Identity}

At first, Ruthenian Protestants showed hostile attitudes towards the faith of their ancestors, Orthodoxy: the former were iconoclasts and treated the Greek faith as their competitor. In 1567 the founder of the Reformation on Ruthenian soil Simon Budny wrote to his cobelievers in Switzerland that the main competition for Protestantism in the GDL came not from Catholicism, but from Orthodoxy. ${ }^{28}$ The Orthodox responded to the spread of Reformation with the work 'A Response to Luther' which came from the Suprasl monastery. This single anti-Protestant treatise has never been published and is available in the form of two manuscripts of 1580 and $1600 .{ }^{29}$

\footnotetext{
${ }^{25}$ Monumenta Reformationis Poloniae et Lithuaniae. Akta synodów prowincjonalnych Jednoty Litewskiej 1611-1625 (Vilnius, 1915), pp. 92-98.

${ }^{26}$ M. Dmitriev, Pravoslavie i reformatsiia. Reformatsionnye dvizheniia v vostochnoslavianskikh zemliakh Rechi Pospolitoi vo vtoroi polovine XVI veka (Moscow, 1990); M. Liedke, Od prawosławia do katolicyzmu. Ruscy możni i szlachta Wielkiego Księstwa Litewskiego wobec wyznań reformacyjnych (Białystok, 2004).

${ }^{27}$ M. Hrushevsky, Istoria Ukraini-Rusi, vol. VI (Kiev, 1995), pp. 422-425.

${ }^{28}$ Kosman, 'Programme', pp. 21-50.

29 Ukrainskaia literatura XIV-XVI st. (Kiev, 1988), pp. 194-197.
} 
During the seventeenth-century Counter-Reformation the necessity for such polemical documents declined.

However, very soon Ruthenian Protestants tried to attach Protestantism to their former historical tradition, namely Orthodoxy. About 1576, a pastor from Vitebsk, Andrei Kolodyński fabricated a document under the title 'The letter of Ivan Smerd to Grand Duke Vladimir' in the guise of a translation from Bulgarian into the Ruthenian. According to the text, in the tenth century the physician of Grand Duke Vladimir of Kiev left for Greece to study medicine. From there he wrote a letter to Vladimir strongly criticizing the practices of the Orthodox Church. However, the most interesting fragment is the one where he narrated that during his travel he came across true Christians among the Slavs, keeping to the Gospel in their everyday life: 'They are quiet and sincere. They have houses of prayers where there are no idols but there are only tables and benches. The Gospel and epistles form their Holy book. They also have a cross. They deny celibacy, fasts and slavery'. ${ }^{30}$

Thus Kolodyński created an ideal picture of Slavic Protestant congregation, which existed already during the rise of Christianity at that part of Europe. His aim here was to ground the traditional nature of the new confession for Ruthenian people. In 1643 an Arian spiritual leader, Andrzej Wiszowaty, the preacher of the congregation in Filipów and a Lithuanian-Ruthenian nobleman by birth and a grandson of the founder of the sect, Faustus Socinus, visited Starodub - an Orthodox district of the GDL. When Wiszowaty crossed the River Dnepr the Ruthenian Arian magnate Jerzy Niemirycz, who followed him, compared Wiszowaty to St Andrew, who according to legend was apostle to the Eastern Slavs. ${ }^{31}$ In this connection Peter Block put forward and argument that most of the Lithuanian Brethren mainly were not ethnic Lithuanians but Belarusian and Polish by origin. ${ }^{32}$

${ }^{30}$ I. Malyshevskii, 'Podlozhnoe pismo Polovtsa Ivana Smerdy k kievskomu kniazu Vladimiru Sviatomu', Trudy III arkheologicheskogo s'ezda v Rossii, vol. II (Kiev, 1878), pp. 307-316.

${ }^{31} \mathrm{G}$. Williams, 'Protestants in the Ukraine during the period of Polish-Lithuanian Commonwealth', Harvard Ukrainian Studies, 2 (1978), pp. 184-210.

${ }^{32}$ P. Brock, 'Antitrinitarians in the Grand Duchy of Lithuania against non-resistance, 1583’, East European Quarterly, 32 (1998), pp.1-8. 
Some modern Polish and Belarusian researchers mistakenly consider that only the Orthodox nobility preserved their Ruthenian identity after the Union with Poland (Lublin, 1569). As was noted by Melecijusz Smotrycki already in 1621 'it is not the Faith that makes a Ruthenian Ruthenian, a Pole Pole, a Lithuanian Lithuanian but his origin and blood, Ruthenian, Polish or Lithuanian'. ${ }^{33}$ Thus, in the seventeenth century, the neophytes - Ruthenian Protestants also regarded themselves as "a people of Rus". The name of one of the districts of the Lithuanian Unity, "Belarusian", speaks for itself. For example, at the Unity synod in 1612 propositions from 'Ruthenian brethren of the noble estate' were presented by a senator, the castellan of Pernau, Piotr Stabrowski. ${ }^{34}$ It is worth noting that while being a Calvinist, from 1597 Stabrowski acted as a protector of the Orthodox population in the district of Slonim. ${ }^{35}$ Another representative of this family and a Calvinist, Jan Stabrowski, gave the Orthodox of Polotsk his own house for worship when their last church had been taken away in $1621 .{ }^{36}$

Protestants rather than Orthodox intellectuals created a number of patriotic works to support Ruthenian identity and language. The appeal of Simon Budny, a translator of Luther's Minor Catechism into Ruthenian, to the founders of the Radvila publishing house, in which he asks the Radvilas to remain faithful to Ruthenian, the tongue of their ancestors, is one proof of that. ${ }^{37}$ Wasyl Ciapiński in the preface of the Gospel published in his own publishing house at his own expense, determined service to the native people as the purpose of the work: 'to serve to my people, since I come from them to serve to my native Rus". ${ }^{38}$ In 1621, a Calvinist noble of Slutsk, Jan Kazimierz Paszkiewicz, composed a patriotic verse in honour of the Ruthenian culture:

\footnotetext{
${ }^{33}$ N. Yakovenko, Paralelni svit. Doslidzennia z istorii uyavlen ta idei v Ukraini XVI-XVII st. (Kiev, 2002), pp. 170-177.

${ }^{34}$ U. Augustyniak, Dwór i klientela Krzysztofa Radziwiłła (1585-1640). Miechanizmy funkcjonowania patronatu (Warsaw, 2001), p. 200.

${ }^{35} \mathrm{~K}$. Chodynicki, Kościót prawosławny a Rzeczpospolita Polska. Zarys historyczny 1370-1632 (Warsaw,1934), pp. 376-385.

${ }^{36}$ T. Kempa, 'Prawosławie i unia we wschodnich województwach WKL w końcu XVII w.', Białoruskie Zeszyty Historyczne, no. 22, pp. 5-41.

${ }^{37}$ Pradmovy i paslasloui pasladounikau Frantsyska Skaryny (Minsk, 1991), p. 25.

${ }^{38}$ Ibid., pp. 33-35.
} 
Poland flourishes with the Latin language

Lithuania blossoms with the Ruthenian tongue

One cannot do without the first in Poland

Without the second one you will be a fool in Lithuania

It is significant that Paszkiewicz's verse was written on the margins of the Lithuanian Statute, the main symbol of Lithuania's independence from Poland. ${ }^{39}$

Fiodor Jewłaszewski may serve as a typical representative of Ruthenian Protestantism. He was a lawyer from Novgorodok. One of the well-known early modern writers of Belarus, and the author of the first memoirs in Ruthenian, this Calvinist was connected closely with Orthodox culture. He received primary education 'in an Orthodox school, since at that time there were no other types of schools in our land'. His father, Michaił was an Orthodox bishop of Pinsk. ${ }^{40}$ Not surprisingly some Reformed manuscripts as, for example, the New Testament, translated by an Arian nobleman Walent Niegaliewski, were used by Orthodox clergy. ${ }^{41}$ The first Ruthenian, who took 'the Belarusian' as his nom de plume, was also not Orthodox, but a Calvinist writer Salomon Rysiński (Solomo Pantherus Leucorussus, ca 1569-1626). Rysiński who was born near Vitebsk, or according to his words 'in Belarus, richly endowed with forests and animals, near the border with frigid Muscovy', received his doctorate from the University of Altdorf and after returning home took up the post of teacher at the Radvila court. ${ }^{42}$

Despite all these facts, some modern Belarusian historians blame the Ruthenian Protestants for Polonization. ${ }^{43}$ Indeed, the Polish language did become dominant in the circles of Ruthenian Protestants during the seventeenth century, as was the case with all confessional groups within the Ruthenian nobility: Orthodox, Roman-Catholic and Uniate.

Relations of Ruthenian Protestants with Orthodoxy Catholic reaction made the Ruthenian Protestants change their attitudes toward

${ }^{39}$ Statut Vialikaha Kniastva Litouskaha, p. 28.

${ }^{40}$ Pomniki memuarnaj litaratury Belarusi XVII st. (Minsk, 1983), p. 32.

${ }^{41}$ A. Nazarevskii, 'Evangelie 1581 goda v perevode W. Niegaliewskogo', Universitetskie izvestia (Kiev, 1911), no. 8, pp. 20-40.

42 J. Poretskii, Salomon Rysiński. Solomo Pantherus Leucorussus, konets XVInachalo XVII veka (Minsk, 1983).

${ }^{43}$ L. Ivanova, 'Refarmacyiny rukh na Belarusi', Belaruski histarychny chasopis, no 2, 1997, p. 72. 
Orthodoxy. In 1569 the Union of Lublin was put into effect. In the same year, Jesuits came from Poland and founded the first college in Vilnius. Most Jesuit schools were opened on ethnic Ruthenian (non-Catholic) soil. In 1585 the Jesuits opened their college in Polotsk, in 1586 in Niasvizh, in 1616 in Orsha, in 1623 in Brest, in 1625 in Minsk and in 1648 in Vitebsk - thus initiating the Counter-Reformation. Alarmed by the mass conversion of the Orthodox nobility to Protestant denominations, the Orthodox Church's hierarchs opted for Union with the Roman Catholic Church and established in Brest in 1596 a new Uniate or a Greek-Catholic Church. King Sigismund III Vasa, the Jesuits and the Catholic elite supported this action. The two first hierarchs of a New Greek-Catholic Church, Metropolitans Adam (Ipaci) Pociej and Jósef Rutski were Calvinists and came from Ruthenian noble families. They both converted from Calvinism to the Greek rite and both became the most active critics of Reformation. ${ }^{44}$ In competition Protestants organized an alternative anti-union Protestant-Orthodox church assembly in Brest in a building belonging to a Calvinist nobleman, Malcher Rajski. An Arian nobleman Demean Hulewicz became its leader. ${ }^{45}$

After the Church Union of Brest the city of Slutsk appeared to be the centre of the Ruthenian Protestants and Orthodoxy. It was the largest private city in the GDL with a population of about 7,000 inhabitants and belonged to the Radvilas. Whereas between 1596 and 1632 the Orthodox Church in Poland-Lithuania was illegal, Slutsk kept ca 45 Orthodox churches in which worship service was legal. Here there was a Protestant grammar school, two Reformed churches (one of them for the Scots) and one Lutheran church. The Slutsk Evangelical grammar school was active until 1917, and became the main educational centre of Belarus.

One of the political aims of Counter-Reformation was to replace the non-Catholic elite. In 1572, Protestants prevailed among the Lithuanian senators ( 16 senators or $73 \%$ ) who together with Orthodox senators ( 3 senators) made $86.5 \%$ in the Lithuanian faction of the Council of Lords. At the same time only three senators were the Catholics, including two Roman Catholic bishops whose positions were guaranteed by law. However, in 1632, the last year of Sigismund III's reign, Catholic magnates represented $100 \%$ of Lithuanian

\footnotetext{
${ }^{44}$ S. Padokshyn, Uniya, dziarzhaunasts', kultura (Minsk, 2000), pp. 57-71.

${ }^{45}$ Lithuanian Metrica. Book 73: National Historical Archives of Belarus, KMF 18, vopis 1 , sprava 73 , pp. $508-509$
} 
senators. ${ }^{46}$ Such state of affairs required political counter-actions. In 1599, a political alliance (a general confederation) between Protestants and Orthodox nobility was proclaimed in Vilnius. Many magnates and nobility joined the confederation to protect Orthodox and Protestant faiths 'from the cunning actions of Catholic clergy'. The signatories declared that Counter-Reformation resulted in the discrimination of non-Catholic nobility in their own country, since their personal confession had a negative effect on their political career. ${ }^{47}$ It is worth noting that the conditions of the treaty were viable and worked efficiently during the seventeenth century. Having amalgamated forces, the Protestants and the Orthodox created a united front at the sejm. ${ }^{48}$

One of the established stereotypes of classical Polish historical scholarship, which has been adopted uncritically by some modern historians, is a myth about plebeian character of Orthodoxy in the GDL in the seventeenth century. Actually, during the whole century the Orthodox nobility constituted a powerful social group including magnate clans. After 1632 Orthodoxy was represented again by senators, the 'elite of elite'. In 1654 it included the following senators: the castellan of Trakai Aleksander Ogiński, the castellan of Novgorodok, Samuel Statkiewicz, the castellan of Minsk, Mikołaj Czetwertyński and the governor of Brest, Maksymilian Brzozowski. At the same time the palatine of Vilnius and grand hetman, Jonušas Radvila, the castellan of Polotsk Jan Sosnowski, and the castellan of Vitebsk, Tomasz Kossakowski, represented the Calvinists. Mikołaj Korff, the castellan of Wenden was delegated from the Lutherans.

The leader of non-Catholic nobility, Jonušas Radvila was a magnate, who owned patrimonies in ethnically different parts of the Grand Duchy and was brought up in Lithuanian and Ruthenian

${ }^{46}$ H. Lulewicz, 'Skład wyznaniowy senatorów świeckich Wielkiego Księstwa Litewskiego za panowania Wazów', Przeglad Historyczny, 68 (1977), pp. 425-445, table 1.

${ }^{47}$ See: Uniya $v$ dokumentakh (Minsk, 1997), pp. 300-307. Regarding the 1599 confederation of Vilnius see: Domet Oljančyn, Zur frage der Generalkonfederation zwischen Protestanten und Orthodoxen in Wilna 1599, Kyrios, 1936, no. 1, pp. 27-46; Gottfried Schramm, Der polnische Adel und die Reformation 1548-1607 (Wiesbaden, 1965); Oskar Wagner, 'Reformation und Orthodoxie in Ostmitteleuropa im 16. Jahrhundert', Zeitschrift für Ostforschung, 35 (1986), pp.18-61.

${ }^{48}$ P. Zhukovich, Seimovaia borba pravoslavnogo zapadno-russkogo dvorianstva s tserkovnoi uniei (1596-1632), vol. 1-8 (St Petersburg, 1901-1912); Chodynicki, Kościót prawosławny, pp. 376-385. 
districts by turns. Therefore his identity developed on his perception of belonging to the state. Being an ethnic Lithuanian, he was an enthusiastic reader of Ruthenian books. ${ }^{49}$ Being the grandson of Wasyl Ostrozki, the main protector of Orthodoxy at the end of the sixteenth century, and a Calvinist, Radvila considered it his duty to support the Orthodox Church. Radvila's marriage to the Orthodox Princess Maria Lupu of Moldavia in 1645 made him the greatest protector of Orthodoxy in the GDL. The news of Radvila's marriage echoed in Scandinavia as a good example of understanding between Protestantism and Orthodoxy. In 1644-45, Russia and Denmark negotiated to conclude an anti-Swedish alliance. The first step of the treaty was to be a marriage of one of the 23 children of the Danish king, Christian IV, his illegitimate son Valdemar Christian, to Irina Mikhailovna, the elder daughter of Tsar Mikhail Romanov of Muscovy. The main obstacle was the demand that Valdemar Christian adopt Orthodoxy. The Russian ambassadors' arguments on the absolute inadmissibility of a marriage between a Lutheran man and an Orthodox woman were objected by a clergyman of the Danish embassy, Matteus Fehlhaber, who alluded to Radvila's marriage to Maria Lupu, blessed by the Ecumenical Patriarchy of Constantinople. ${ }^{50}$

Strong ties connected Radvila's faction with the Orthodox magnate kin of Ogiński. ${ }^{51}$ It was the magnate families of the Ogińskis and Statkiewiczes together with the representatives of such famous families as the Wołłowiczes, Drucki Sokolińskis, Massalskis, Chodkiewiczes, Łomskis, Sapiehas, Tryznas, Meszczeryns and Onichimowskis who were the sponsors of Orthodox Church and Ruthenian culture during seventeenth-century Catholic reaction. ${ }^{52}$ The Orthodox publicists of that time called the clan of Ogiński 'the bastion of our faith'. The

${ }^{49}$ L. Scchavinskaia, 'Iazykovoi fenomen cheloveka polsko-vostochnoslavianskogo-litovskogo pogranichia XVII veka: Vilniuskii voevoda Janusz Radziwill-chitatel' kirilicheskikh tekstov', Studia Russica, 17, pp. 129-132.

${ }^{50}$ T. Oparina, Ivan Nasedka i polemicheskoe bogoslovie kievskoi mitropolii (Novosibirsk, 1998), p. 235. Prince Valdemar Christian and the Danish diplomats have got this information directly from Janusz Radziwiłł. The Danish embassy moved to Moscow via Lithuania and Radziwiłł met it in Vilnius. See: E. Kotłubaj, Życie Janusza Radziwiłta (Vilnius-Vitebsk, 1859), pp. 73-74.

${ }^{51}$ M. Liedke, 'Suviazi Aginskikh z pratestantstvam u pershaj palovie 17 st.', Histarychny Almanakh, 5 (2001), pp. 105-112.

${ }^{52}$ Kniha Belarusi. Zvodny kataloh. 1517-1917, nos. 70-79, 99-100, 117-123. 128-129, 136-137, 152, 158-160. 
Ogiński clan enjoyed political domination in the palatinate of Vitebsk. Their palace in Vitebsk, built in the first half of the seventeenth century by Samuel Ogiński, was a symbol of the clan's wealth. Until the beginning of the nineteenth century, it was the largest public building in the city. The owner of the palace - the Orthodox Prince Samuel Ogiński studied in Holland at the University of Franeker. There he married the daughter of the local burgomaster, van Staakman and brought her to Vitebsk. ${ }^{53}$ The Orthodox origin of Ogiński prevented him from becoming a senator. However, Ogiński had more political influence and power in the palatinate of Vitebsk than the palatine sent by Warsaw. In 1653 one Catholic noble from Vitebsk wrote that 'Samuel Ogiński, not the palatine, has all power here, he is like a plague to the local nobility'. ${ }^{54}$ At the same time the family of Statkiewicz dominated the political life of Mstsislav. ${ }^{55}$

The Restoration of Orthodoxy and the Role of Protestants The centre of political struggle for religious freedom for the Orthodox nobility was the Vilnius Brotherhood of the Holy Spirit founded in 1596. The protectors of the brotherhood in the seventeenth century were the representatives of the Orthodox (Ogiński and Statkiewicz) and Calvinist (Radvila) magnates. ${ }^{56}$ As a result of political struggle on October 31 1632, King Władysław Vasa signed 'Articles to soothe the Orthodox Church' proposed by non-Catholic nobles. This resulted in foundation in the GDL the eparchy of Belarus with its centre in Mogilev. The bishop of Belarus was to be elected in accordance with old traditions of consultations with nobility and had to be 'of noble origin'. Outside the Belarusian episcopate, the Orthodox of the GDL were allowed to have monasteries and churches in Vilnius, in the districts of Trakai, Brest, Minsk, Polotsk and Slutsk. That was a triumphal victory for the dissident party. After having been

${ }^{53}$ L. Khmialnitskaia, 'Rod fundatarau i metsenatau. Ahinskiia', Vitsebski sshytak, 1995, no. 1, pp. 42-47.

${ }^{54}$ H. Lulewicz, Elita polityczno-spoleczna Wielkiego Księstwa Litewskiego $w$ połowie XVII wieku. Praca doktorska, unpublished manuscript (Warszawa, 1984), p. 74 .

${ }^{55}$ T. Kempa, 'Kariery przedstawicieli prawosławnych rodów Ogińskich i Stetkiewiczów w XVII wieku - podobieństwa i różnice awansu społecznego, ekonomiczniego i polityczniego', Władza i prestiż: magnateria Rzeczypospolitej w XVI-XVIII wieku, ed. J. Urwanowicz (Białystok, 2003), pp. 345-368.

${ }^{56}$ T. Kempa, 'Wileńskie bractwo Św. Ducha jako centrum obrony prawosławia w Wielkim Księstwie Litewskim w końcu XVI i w pierwszej połowie XVII w.', Białoruskie Zeszyty Historyczne, 21, pp. 47-69. 
outlawed for 26 years, the Orthodox Church resumed its legitimacy as well as the rights of free worship service and to build churches, publishing houses and schools. Making an analysis of the list of renascent Orthodox centres, one cannot but notice that in many places the Orthodox and Reformed Churches existed close to each other. The restored churches arose mainly in the places where a Protestant parish existed. Those included Minsk, Polotsk, Mogilev, Vitebsk, Brest, and Halouchyn. One of the founders of a new building of a legal Orthodox church in Polotsk (1633) was a Calvinist noble, Sebastian Mirski. ${ }^{57}$

Namely the Protestant branch of the Radvilas became the largest sponsor of the Orthodox Church. Until the end of the seventeenth century the Radvilas made about 50 endowments to the Orthodox Church on their territory. ${ }^{58}$ A number of new Orthodox churches were built by the Radvilas in their private towns (Kèdainiai, Slutsk, Zabłudów, Orla, Sialets). These facts are the evidence of the success of Orthodox-Protestant alliance. However, despite the legitimization of the Orthodox Church, the struggle between the Orthodox and the Catholics did not stop since the Orthodox Church demanded restitution of churches taken by Greek-Catholics. Under pressure from the dissident nobility King Władysław Vasa admitted this proposition was reasonable. That caused a number of new court disputes between the Orthodox and Greek-Catholics and required further coordination of political activity by the Ruthenian Orthodox and the Protestants. ${ }^{59}$ Because of the support of Palatine Jonušas Radvila, in 1653 the Orthodox merchants of Vilnius won back three Uniate churches, which previously had belonged to them. ${ }^{60}$ In turn the Ruthenian merchants of Vilnius ('ryska köpmän från Vilna') appreciated Radvila's assistance and paid him back with finances and diplomatic support for Radvila's pro-Swedish policy. ${ }^{61}$ The demand to respect the rights of dissidents during sejms in the

${ }^{57}$ Kempa, 'Prawosławie i unia', p. 35.

${ }^{58}$ U. Augustyniak, 'Żródła do badania stosunków wyznaniowych i narodowościowych w WKL XVII w. w Archiwum Warszawskim Radziwiłłów’, Miscellanea Historico-Archivistica, vol. VII, pp. 155-167.

${ }^{59}$ V. Panucevich, Sviaty Jazafat, arkhiiapiskap polatski, (Polotsk, 2000), pp. 135-150.

${ }^{60}$ Arkhiu uniyatskikh mitrapalitau. Davednik (Minsk-Polatsk, 1999), p. 53.

${ }^{61}$ Magnus Gabriel De la Gardie to Karl X. August 1, 1655 (July 22, 1655, according to the old Swedish calendar). Riga. Swedish. In: RA/Riksarkivet. Livonica II. Vol. 77. Generalguv. i Livland till K. MAJ:T 1655-56. 
mid-seventeenth century was evidence of the consolidated position of the Protestant and Orthodox nobility. The Protestant senators, Radvila and Abramowicz, demanded the king preserve the rights of nonconformists. Orthodox senators, Aleksander Ogiński and Bohdan Statkiewicz, and sejm envoys, Bohdan Ogiński (Trakai), Michał Statkiewicz (Mstsislav) and Jerzy Nielubowicz Tukalski (Pinsk), as usual joined the demand of Protestants. ${ }^{62}$

In response to the royal policy of confessionalization, the Ruthenian Protestants worked out the tradition of exclusion marriages in accordance with which marriages were welcome with the Orthodox nobility. ${ }^{63}$ Marriages between Protestants and Orthodox arose. Consequently some sons of the nobility belonged to Protestantism and some to Orthodoxy. The families of the Massalski, Łomski and Mirski were among them. The wealthy ennobled merchant Belarusian family of Łomski from the district of Orsha can serve as an example. In 1654 one representative of this family, Mikołaj Lomski, was a member of the Mogilev Orthodox brotherhood. ${ }^{64}$ At the same time, Protestant representatives of the clan were the main patrons of Reformed Church in Kopys. ${ }^{65}$ One of them, Daniel Łomski joined the diplomatic service of the Principality of Transylvania and its Calvinist ruler György II Rákóczi. ${ }^{66}$

The spread of Lutheranism even among the Slavic population of capital Vilnius made the Catholics feel uneasy. To stop this influence the Jesuits issued a pamphlet in Ruthenian with criticism of Lutheran pastors and especially their relations with the Orthodox Ruthenians. ${ }^{67}$ Indeed the Lutherans taught in the Orthodox school in Vilnius. ${ }^{68}$ Lutheran books were issued by the Orthodox publishing

${ }^{62}$ Volumina Legum, IV (St Petersburg, 1859), pp. 85-97.

${ }^{63}$ Augustyniak, Dwór i klientela, p. 125.

${ }^{64}$ Spisok bratstva pri tserkvi Bogoiavlenia Gospodnia Mogileva (1634-1734), Arkheograficheskii sbornik dokumentov, otnosiashchikhsia k istorii Severo-Zapadnoi Rusi V (Vilnius, 1871), pp. 125-126.

${ }^{65}$ W. Kriegseisen, Ewangelicy Polscy i Litewscy w Epoce Saskiej (Warsaw, 1996), pp. 107.

${ }^{66}$ S. Sziláfyi, 'Erdély és az északkeleti háború, levelek és okiratok', Transsylvania et bellum boreo-orientale. Acta et documenta, II (Budapest, 1891), pp. 72-73.

${ }^{67}$ Witanie na pierwszy wiazd z Królewca do Kadłubka Saskiego Wileńskiego Ixa Her N. Lutermachra: na własne kleynoty Lutermachra. Drukowano w Witembergu roku 1642 dnia wczorayszego, Wittenberg [in fact in Wilna in Ruthenian and Latin script] 1642.

${ }^{68}$ Kempa, 'Wileńskie bractwo’, p. 56. 
house. ${ }^{69}$ Orthodoxy became the object of thorough examination by the Lutheran pastor of Vilnius, the first rector of the German lyceum in Stockholm, Johannes Herbinius. ${ }^{70}$ It was in Vilnius in $1673-75$ that Herbinius wrote the principle book of his life - the first in the West, a history of the Kievan Caves Monastery. ${ }^{71}$ Protestants supported Orthodox merchants and nobles in their desire to preserve the old Julian calendar (convenient, above all, for trade contacts with Swedish Riga). The Protestants of the Belarusian district maintained the Julian calendar until the end of the seventeenth century, which demonstrated accord with the Orthodox tradition. Thus the Lithuanian Unity published the Reformed calendars with two parallel dates in accordance with the new and old Orthodox style. ${ }^{72}$ Under the influence of Protestant thought, innovation tendencies are traced in the local Orthodox thinking. Orthodox activists demanded that believers should fast not only bodily but also spiritually, calling for individual reading of the Bible. ${ }^{73}$ Meanwhile the local Calvinists borrowed from Orthodoxy the tradition of distributing alms to beggars after divine service. ${ }^{74}$ As a result, whereas in the sixteenth century Ruthenian Protestants considered Orthodoxy to be idolatrous, in the seventeenth century they changed their opinion and Orthodoxy became a faith that had an alternative way to the Heaven. ${ }^{75}$

${ }^{69}$ A. Schonflisius, Cora Iairowa zmarla od Chrystusa $w$ zbudzona na pogrzebie cney y pobozney panny Anny Debowskiey szlachetnego pana Marcina Debowskiego aptekarza y mieszczanina Wilenskiego... (Vilnius, 1636).

${ }^{70}$ H. Bendel, Magister Johannes Herbinius. Ein Gelehrtenleben aus dem XVII. Jahrh. (Bern, 1924).

${ }^{71}$ J. Herbinius, Religiosae Kijovienses Cryptae, sive Kijovia Subterranea: in quibus labyrinthus sub terra, et in eo emortua, a sexcentis annis, Divorum atque Heroum Graeco-Ruthenorum, \& nec dum corrupta, corpora, ex nomine atque ad oculum, e Pateriko sclavonica detegit, (Jena 1675). See facsimile in: Seventeenth-century writings on the Kievan caves monastery, ed. by Paulina Lewin (Harvard, 1988).

${ }^{72}$ For several editions of the Protestant calendars for 1654-1657 see: M. Ivanovic, XVII a. Lietuvos lenkiškos knygos. Kontrolinis sqrašas (Vilnius, 1998), nos. 167-170.

${ }^{73}$ M. Dmitriev, 'Izmeneniia v kulturnoi i ideinoj zhizni Rechi Pospolitoi v epokhu Reformatsii i pravoslavnoe obshchestvo', Brestskaia uniia 1596 i obshchestvenno-politicheskaia borba na Ukraine i v Belorussii v kontse XVI-nachale XVII vv., vol. 1: Brestskaia uniia 1596 g. (Moscow, 1996), pp. 42-60.

${ }^{74}$ Kriegseisen, Ewangelicy Polscy i Litewscy, p. 91.

${ }^{75}$ R. Degiel, Protestanci i Prawostawni. Patronat wyznaniowy Radziwiłlow birżańskich nad Cerkwia prawoslawna $w$ Księstwie Stuckim w XVII w. (Warsaw, 2000), p. 151. 
Protestant nobles viewed their Orthodox subjects not only as friends but also as a potential group of future co-believers. In accordance with Radvilan plans, the Evangelical grammar school in Slutsk was supposed to introduce a course of Greek theology to be read by an Orthodox professor with the status of vice-rector 'who could attract young Ruthenians from the neighbourhood'. ${ }^{76}$ It is known that the local Orthodox merchants joined Evangelical communities in Vitebsk and Kopys. ${ }^{77}$ In 1630 the count of Orla, Stanisław Kurocz put up a campaign to attract native Orthodox Ruthenians to the local Reformed church. ${ }^{78}$ Protestants encouraged Orthodox children in Vitebsk to go to school at the Reformed cathedral. ${ }^{79}$ It was absolutely possible for Orthodox believers to convert to Protestantism. In 1619 a Ruthenian priest, Hrehory Bańkowski converted from Orthodoxy to Calvinism. Next year he became a Reformed priest of the town of Astashyn 'in Rus'. However, in 1623 the synod of Jednota Litewska forbade him to visit the Orthodox church of Chernyshova and preach there. ${ }^{80}$

However, the general attitude of many Protestant nobles to their Orthodox brothers was as critical as before. In 1629, the land judge of Brest Piotr Kochlewski wrote to Krzysztof II Radvila that he could not accept 'the pagan idol-mania of Orthodoxy and its vile tradition of kissing dead lips', that in Kochlewski's logical opinion was the reason for epidemics. ${ }^{81}$ In 1636 the synod suggested to the Protestant noble Kaspar Żernicki that he avoid worship at the Orthodox church in Zhlobin. ${ }^{82}$ Protestant administrators of Slutsk tried to improve the religious discipline of Orthodox Ruthenian farmers by the method of Martin Luther. Each village clergyman had to record the believers into special record-book. Each absentee from divine service had to pay a fine. ${ }^{83}$

Conclusions Poland-Lithuania's wars with Russia, Ukraine and Sweden (1654-1667) became a catastrophe for the GDL and marked

${ }^{76}$ Ivanova, 'Refarmacyiny rukh', pp. 54-72.

${ }^{77}$ L. Ivanova, 'Z historyi refarmacyjanaj tsarkvy u Vitsebsku u druhaj palove XVI-XVII stst.', Vitsebski shytak, no. 2, 1996, pp. 41-45.

${ }^{78}$ Augustyniak, Dwór i klientela, p. 230.

${ }^{79}$ Ivanova, 'Z historyi', p. 45.

${ }^{80}$ Monumenta Reformationis Poloniae et Lithuaniae, pp. 51, 53, 79.

${ }^{81}$ Augustyniak, 'Żródła do badania', p. 165, note 66.

${ }^{82} \mathrm{H}$. Wisner, 'Książęta na Birżach i Dubinkach a przymus wyznaniowy na Litwie pierwsza połowa XVII wieku', Nash Radavod, 4, 1992, pp. 303-313.

${ }^{83}$ Degiel, Protestanci i Prawostawni, p. 101. 
the end of the Protestant-Orthodox cooperation. The Duchy lost 48.4 per cent of its population. ${ }^{84}$ Muscovite and Cossack troops seized all Cyrillic printing houses and destroyed several Protestant religious centres. At the same time the Protestants and Orthodox could be accused of collaboration with the two main enemies of Poland: Sweden and Russia. A strong anti-Protestant and anti-Orthodox propaganda campaign started. The Catholic Church treated the Swedish and Russian invasion as God's revenge for allowing the Protestants and Orthodox to live in peace. Eventually most of the Ruthenian nobility converted to Catholicism, also taking with them the parishes situated on their lands, as well as many of their subjects. During the Second Northern War (1656-1660) many Lithuanian-Ruthenian Protestants supported Sweden and served in the Swedish army. By the order of Swedish governor of Riga and Livonia, Magnus Gabriel De la Gardie, a special Lithuanian regiment of Polish cavalry was formed led by Lithuanian Germans Wilhelm Korff and Ernst Jan Korff. Their soldiers fought against the rebels. ${ }^{85}$ Before the uprising, Mikołaj Wysocki, a noted Protestant from the GDL, entered Swedish service. His cousins, Johan and Ludvig Wisocki-Hochmuth were already the officers of Swedish army. ${ }^{86}$ Boguslovas Radvila explained Wysocki's wish to be a Swedish officer:

Captain Mikołaj Wysocki showing his determination to be on the king's side, though the Confederates called on him and his company to switch to their side, however, told me that he wanted to make his way to Žemaitija to place himself under the command of Your Excellency. ${ }^{87}$

For his collaboration with Sweden, the king of Poland-Lithuania Jan Kazimierz Vasa denounced Mikołaj Wysocki as 'a traitor' and gave his patrimony to the energetic rebel Teodor Lacki. ${ }^{88}$ After the

${ }^{84}$ J. Morzy, Kryzys demograficzny na Litwie i Białorusi w II połowie XVII wieku (Poznań, 1965), table 23.

${ }^{85}$ R. Fagerlund, Kriget $i$ Östersjöprovinserna 1655-1660. Operationer och krigsansträngningar på en bikrigsskådeplats under Carl X Gustafs krig (Åbo, 1979), p. 63.

${ }^{86}$ Their father Jan Wysocki (Johan Wisotzki) moved to Sweden from Lithuania during the First Northern War. Lieutenant Johan Wisocki Junior was married to Proscowia Aminoff from Ingermanland, a Swedish noblewomen of Russian origin.

${ }^{87}$ Bogusław Radziwiłł to Magnus De la Gardie. 3 March 1656. Tykocin, French. RA. De la Gardieska Samlingen. Skrivelser till M. G. De la Gardie. Ser. C:I. E 1531.

${ }^{88}$ Metryka Litewska. Księga wpisów nr 131, ed. A. Rachuba (Warsaw, 2001), no 108 . 
war the Wysocki family remained in Sweden and was introduced into the Swedish House of Nobility. ${ }^{89}$

The last GDL Protestant senator Jan Sosnowski converted to Catholicism in 1664. In 1667, the Orthodox prince, Aleksander Ogiński died. He was the last senator in the history of Poland-Lithuania who was not a Catholic. In 1669, the last Orthodox magnate Marcjan Ogiński was forced to convert to Catholicism. He had to choose between the Roman Catholic or Uniate faith. It was an obligatory requirement of authorities and the main condition for him to continue his political career. ${ }^{90}$ From 1678 for more than 10 years the only remaining Orthodox bishopric of Belarus was without any bishop at all. ${ }^{91}$ Thus, without great patrons the Protestant and Orthodox churches soon became subject to attacks by Catholics.

After 1667 many prominent Ruthenian Protestants emigrated to Muscovy, where they converted to Orthodoxy and enlarged the number of outstanding cultural workers of Peter the Great's Russia. Among them were Elias Kopiewicz (1651-1714), the major publisher of Russian books in Europe and Jan Manuel Byaloboczky (1650-1700), a famous Russian writer. ${ }^{92}$ At the end of the seventeenth century the Orthodox nobility gradually attained the status of insignificant religious minorities..$^{93}$ Thus the Counter-Reformation was successful.

However, during the eighteenth century, the idea of a ProtestantOrthodox alliance became relevant again. In 1710, during the Great Northern War, a leader of the Ruthenian Protestants, Michal WołkLaniewski elaborated a programme for the political struggle for the rights of dissidents. This programme was aimed for the most part at a political union with Orthodoxy and help from Russia. In 1735 a delegation of Ruthenian dissidents visited St Petersburg with the requests of such help. It is significant that the delegation

${ }^{89}$ A. Kotljarchuk, In the Shadows of Poland and Russia: the Grand Duchy of Lithuania and Sweden in the European Crisis of the mid-17 th Century, 2006, pp. 176-179, 272-279.

${ }^{90}$ Lulewicz, 'Skład wyznaniowy', p. 443.

${ }^{91}$ H. Sahanovich, Narys historyi Belarusi da kantsa 18 st. (Minsk, 2002), pp. 291-292.

${ }^{92}$ A. Kotljarchuk, "Brain drain" of the Protestants from the Grand Duchy of Lithuania in the $17^{\text {th }}$ century and the Catholic counter-reformation', Spadchyna, 2006, no. 1, pp. 65-78.

${ }^{93}$ A. Mironowicz, Prawostawie i unia za panowania Jana Kazimierza (Białystok, 1997). 
was represented by all three oppressed confessions: Calvinism, Lutheranism and Orthodoxy. ${ }^{94}$

During the second half of the eighteenth century, Prussia and Russia began to play the dissident card. The text of the 1599 Vilnius confederation has been taken from the Secret Archive in Berlin. ${ }^{95}$ Organized by Russia, the 1767 Confederation of Slutsk marked the culmination of the policy of neighbouring states. About 800 Protestant nobles and three Orthodox noblemen from Belarus arrived in Slutsk. On March 18 1767, 130 participants signed the act of confederation, led by the Orthodox bishop of Belarus, Hrehory Konisski, and the Calvinist general of the Lithuanian army, Jan Grabowski, with the demand from Warsaw to resume the religious liberties and with the request to the governments of Russia, Prussia and Sweden for foreign aid. ${ }^{96}$ The Slutsk Confederation symbolized the beginning of the disappearance of the GDL from the political map of Europe. This was the last act of cooperation between the Protestant and Orthodox elite in the history of Belarus.

\section{Author Details}

Dr Andrej Kotljarchuk (1968) is a university lecturer in history at the School of History and Gender Studies, Södertörns högskola (Stockholm). Main research interests: Early modern political, cultural and religious contacts between Sweden, Belarus, Lithuania, Ukraine and Russia. Swedish history and its connection to the history of Eastern Europe. Ethnic and confessional minorities. His publications include three monographs: The official festival culture in towns of Russia and Belarus in 17th century (2001); Swedes in Belarusian history and culture (2002); In the Shadows of Poland and Russia: the Grand Duchy of Lithuania and Sweden in the European Crisis of the mid-17th Century (2006);

Email: andrej.kotljarchuk@sh.se

${ }^{94}$ Kriegseisen, Ewangelicy Polscy i Litewscy, pp. 228-231.

95 J. Lukaszewicz, Dzieje kościołów wyznania helweckiego w Litwie, I (Poznań, 1842), pp. 394-395.

${ }^{96}$ J. Anishchanka, Litouskaya pravintsya u padzelakh Rzeczypospolitej. Inkarparatsya (Minsk, 2003), pp. 102-104. 


\section{RUTĖNŲ PROTESTANTAI LIETUVOS DIDŽIOJOJE KUNIGAIKŠTYSTĖJE} IR JŲ SANTYKIAI SU STAČIATIKYBE 1569-1767 M.

Santrauka

\section{ANDREJ KOTLJARCHUK}

XIX a. Rytu Europoje formuojantis modernioms tautinèms tapatybėms, Baltarusija neteko savo išsilavinusių socialinių sluoksnių, rutẻnų elito, kuris būtų galèjęs valdyti tokị tautini judẻjimą. Šią padètị nulèmẻ keletas priežasčių. Pirma, XVII-XVIII a. Kontrreformacija i̇veike Reformaciją ir Stačiatikių bažnyčią LDK žemèse. Po 1667 m. būti kataliku reiškè būti ištikimu Lenkijos-Lietuvos valstybei. Palaipsniui stačiatikiai ir protestantai rutènų bajorai bei biurgeriai perejo į Romos katalikybę, ir kartu perėmė lenkų religinę kultūrinę tapatybę pagal formuluotę gente ruthenus, natione polonus. Retas istorikas yra tyrinejęs LDK (Lietuvos, Žemaitijos, Rusios) rutènų bajorų, ypač protestantų, praeiti. Šio straipsnio autorius analizuoja valstybės elitui priklausiusių rutėu protestantų ir stačiatikių tarpusavio santykių istoriją ankstyvesniais naujaisiais laikais. 